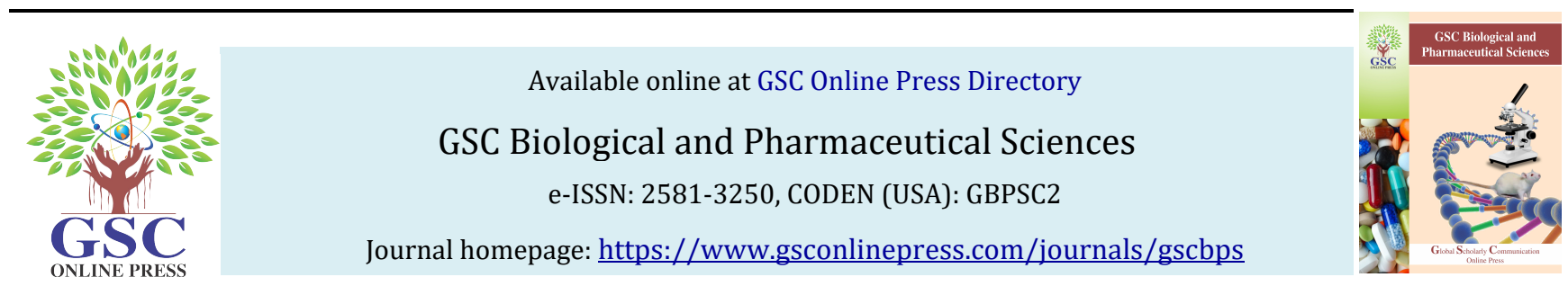

(RESEARCH ARTICLE)

\title{
Performance assessment of Bhendi hybrid Co 4 cultivation over local check variety under Front Line Demonstration
}

\author{
V. Sivakumar ${ }^{1,}{ }^{*}$, S. Praneetha ${ }^{2}$, R. Balakumbahan ${ }^{3}$, B. Meena ${ }^{4}$, G. Thiyagarajan ${ }^{5}$ and M. Alagar 6 \\ ${ }^{1}$ Assistant Professor [Horticulture], Tamil Nadu Agricultural University, Coconut Research Station, Aliyarnagar, \\ Coimbatore - 642101. \\ ${ }_{2}^{2}$ Professor and Head, Tamil Nadu Agricultural University, Coconut Research Station, Aliyarnagar, Coimbatore - 642101. \\ ${ }^{3}$ Assistant Professor [Horticulture], Tamil Nadu Agricultural University, Horticultural College and Research Institute, \\ Periyakulam, Theni - 625604. \\ ${ }^{4}$ Associate Professor [Plant Pathology], Tamil Nadu Agricultural University, Coconut Research Station, Aliyarnagar, \\ Coimbatore - 642101. \\ ${ }^{5}$ Assistant Professor [SWCE], Water Technology Centre, Tamil Nadu Agricultural University, Coimbatore - 641003. \\ ${ }^{6}$ Assistant Professor [Agrl. Entomology], Tamil Nadu Agricultural University, Coconut Research Station, Aliyarnagar, \\ Coimbatore - 642101.
}

Publication history: Received on 03 October 2020; revised on 09 October 2020; accepted on 12 October 2020

Article DOI: https://doi.org/10.30574/gscbps.2020.13.1.0328

\begin{abstract}
A field investigation on productivity augmentation of bhendi [Abelmoschus esculentus L. Moench] was carried out at Melanagai village, Mannargudi block of Thrivarurur district. The study was conducted by ICAR-Krishi Vigyan Kendra, Needamangalam [Tamil Nadu], during 2016-17 to assess the bhendi/okra hybrid Co 4 performance along with local check variety.The per cent yield improvement, technology gap, extension gap, technology index were calculated based on the observation recorded on growth, yield and economical attributes of both demonstration and local adopted check variety. The recorded data showed that the average yield of demonstration plots was 20.35 tha $^{-1}$ whereas the local check recorded an average yield of 12.80 tha $^{-1}$ and there is an amplified average yield by 37.21 per cent. The gross returns and benefit cost ratios from the demonstration plot were higher [Rs. 121020/ha and 2.80 respectively] as compared to farmer's practices [Rs. 76800/ha and 1.90]. The demonstrated improved variety i.e. okra hybrid Co 4 recorded superior growth, yield and economical parameters of the local adopted check variety. The enhancement in growth, yield and economic parameters under okra hybrid Co4 than the farmers' practice [local check] signifying the technical and economic viability of improved variety / hybrid over farmers practices.
\end{abstract}

Keywords: Bhendi Hybrid Co4; Local Check Variety; improved cultivation practices; Field Performance; Growth Parameters; Yield Parameters; Cost Economics

\section{Introduction}

The main occupation of Thiruvarur district is primarily "Farming". This area depends mostly on Cauvery river water for irrigation purpose. Although, this district is called as rice bowl of Tamil Nadu because of paddy cultivation in larger area and for all the three seasons, horticulture crops are also being cultivated in an area of 1534 ha. Among the vegetables cultivated in this district, okra plays a significant role for periodical income of small and marginal farm holdings. Abelmoschus esculentus L. Moench is also called as Okra/Bhendi or lady's finger in India, which is one of the most

${ }^{*}$ Corresponding author: V. Sivakumar

Assistant Professor [Horticulture], Coconut Research Station, Aliyarnagar, Coimbatore - 642101.

Copyright (@ 2020 Author(s) retain the copyright of this article. This article is published under the terms of the Creative Commons Attribution Liscense 4.0. 
fashionable vegetables grown through out of the tropical, sub-tropical and warm temperature regions of the world. The origin of bhendi is considered as South Asia, Ethiopian and West African origins [1]. Bhendi is gaining importance with regard to its nutritional, medicinal and industrial value. It is rich in various nutrients and average nutritive value of okra is3.21 per cent. It is a good source of folic acid, vitamin B, vitamin C providing 21.1 per cent of daily value for a 2000 calorie and has high dietary fibre content. Bhendi has anti-diabetic property which helps in reducing blood sugar levels, while in Turkey roasted okra seeds have been used as a traditional diabetes medicine for generations. Bhendi has highest amount of iodine which prevents from goitre disease. Bhendi also helps in preventing constipation, lowering cholesterol, aids in treating sore throat, irritable bowl, ulcers and lung inflammation. Bhendi has various industrial uses and young immature pods of okra can be consumed in different forms [2]. The fruits are harvested when immature and eaten as vegetable. The tender leaves of bhendi often used as a vegetable in areas where a wide variety of leaves are used as greens [West Africa, South East Asia]. Mature fruits containing crude fibre are used in the paper industry. Its ripe seeds can be dried, roasted and ground to be used as a coffee substitute [3].Between these schemes, Frontline Demonstration [FLD] is one, which highlights to escalate productivity by contributing critical inputs along with amended cultivation of practices established by scientists of research Institutes and State Agricultural Universities [SAUs]. Using improved seed, adoption of seed rate, seed treatment, sowing time, recommended dose of fertilizer, weed control and plant protection measure generate higher yield of okra as compared to farmer's practices. Extending cultivation of improved varieties, getting feedback from farmers about constraints in adoption of recommended improved technologies for further research and to maximize the technology dissemination process among the farmers are some of the other important features of this programme [4]. Keeping these in mind, the present study was conducted to assess the impact of frontline demonstration on yield and economics of okra production.

\section{Material and methods}

The field experiments i.e. Front Line Demonstrations [FLD] on bhendi hybrid Co 4 were conducted in ten farmers field. The investigation was carried out by the ICAR-Krishi Vigyan Kendra, Needamangalam, to study the production and financial viability of scientific farming methods on Bhendi at Thiruvarur district during June to September and October to December season [two successive seasons] of 2016-17 in the farmer field at Mannargudi, Needamangalam and Nannilam blocks. The study was implemented in an area of 10 hectares with acreage of 1 hectare per farmer under front line demonstration with dynamic involvement of farmers in particular village. Before initiation of FLDs, the group meetings and skillfulness trainings were conducted for the selected farmers with reference to various aspect of Bhendi cultivation. To demonstrate the scientific bhendi production technology, constrains in bhendi production were categorized though participatory approach preferential ranking technique.

Formerly the farmers were practiced to cultivate the traditional bhendi variety with low yield potential i.e. 10-12tonnes per hectare which is highly susceptible to yellow vein mosaic virus disease due to the lack of awareness on latest high yielding bhendi hybrid Co 4. Primarily ICAR-KVK, Needamangalam has given technical knowledge on bhendi production and a few important significant inputs viz., seeds and nutrient formulations i.e., IIHR vegetable special etc., The cultivation practices demonstrated were using improved hybrids, seed treatment, maintenance of optimum plant population, application of recommended dose of fertilizer. The seed were sown at plant spacing of $0.45 \mathrm{~m} \times 0.30 \mathrm{~m}$ with the seeds rate of $2.5 \mathrm{~kg} / \mathrm{ha}$. All participatory growers were educated on all aspects of bhendi production techniques. To study the viability and economic feasibility of the front line demonstration, 10 active farmers were selected from 50 respondent farmers through proportionate sampling method. Observation on Growth, yield characters and economics on FLDs and indigenous adopted practices were recorded. The recorded data were compared and statically analyzed. The extension gap, technology gap and technology index were calculated using the formula suggested by Samuiet al.,[5], Kadianet al.,[6], Sagar and Chandra [7] and Sivakumaret al.,[8].Client Satisfaction Index [CSI] was calculated by using formula developed by Kumaran and Vijayragavan[9].

\begin{tabular}{|l|l|}
\hline Particulars & Formula \\
\hline Extension gap $\left[\mathrm{qha}^{-1}\right]=$ & Demonstration yield $\left[\mathrm{qha}^{-1}\right]-$ yield of local check $\left[\mathrm{qha}^{-1}\right]$ \\
\hline Technology gap $\left[\mathrm{qha}^{-1}\right]=$ & Potential yield $\left[\mathrm{qha}^{-1}\right]-$ Demonstration yield $\left[\mathrm{qha}^{-1}\right]$ \\
\hline Technology index $[\%]=$ & Technology gap / Potential yield x100 \\
\hline Client Satisfaction Index $[\mathrm{CSI}]$ & Individual obtained score/ Maximum score possible \\
\hline
\end{tabular}




\section{Results and discussion}

\subsection{Constrains in bhendi cultivation}

Field bottle necks on Bhendi growing locations were documented during field experimentation. Preferential ranking for scientific techniques were utilized to classify the troubles encountered by the respondent farmer in respective villages. The conditions explained by the various farmers is furnished in Table 1. On examination of the constrains, it was clearly indicated that lack of suitable high yielding hybrid [85.00\%] was in the first position followed by lack of technical knowledge on cultivation [75.00\%]. In respect of these ranks suggested by the farmer for the different constraint exposed that lack of suitable high yielding varieties, low technical knowledge, labour problem, low soil fertility status and other constraint such as marketing of the farm produce were the reason for reduction of bhendi cultivation area in Thiruvarur district. Among all these limitations, marketing of the farm produce and water scarcity got least concerns. Similar studies results were also reported by Dhaka et al., [10], Ranawat et al., [11], Sreelakshmi et al., [12], Sivakumar et al., [8] their varietal demonstration studies.

Table1 Ranking by farmers for various constraints [n=100]

\begin{tabular}{|l|l|l|l|}
\hline S. No. & Constraints & Percentage & Ranks \\
\hline 1. & Lack of high yielding varieties & 85.00 & I \\
\hline 2. & Labor problem & 55.00 & III \\
\hline 3. & Low soil fertility & 40.00 & IV \\
\hline 4. & Marketing of the farm produce & 35.00 & V \\
\hline 5. & Low technical know how & 75.00 & II \\
\hline 6. & Water scarcity through canal & 30.00 & VI \\
\hline
\end{tabular}

\subsection{Growth characters}

Plant morphological, flowering, fruit and yield parameter were significantly influenced due to the usage of hybrid Co 4 seeds for cultivation and adopted improved production techniques over local practices. [Table 5]. Significantly, the higher values for plant height [125.3 cm], number of branches per plant [3.4], number of fruit per plant [20.4], individual fruit weight [15.6 g], fruit length [13.7 cm], fruit girth [7.1 cm], yield per plant [437.8 g] and yield per ha [203.5 q/ha] were recorded by the bhendi hybrid Co 4 . The least values for the mentioned characters were observed under local check variety under farmers adopted cultural practice. Lesser days taken for 50 per cent flowering [51.0 days] and first fruit harvest [ 40.9 days] and least incidence of Yellow Vein Mosaic disease [3.8\%] were recorded by using bhendi hybrid Co 4.

\subsection{Performance of FLD}

Results of frontline demonstrations revealed that the improved hybrid i.e. TNAU bhendi hybrid Co4 along with precise cultivation techniques emphasized under demonstration produced on an average of 37.21 per cent more tender fruit yield of bhendi as compared to farmer's practices [Table 3]. The improved hybrid recorded a higher tender fruit yield $20.35 \mathrm{t} \mathrm{ha}^{-1}$ whereas the local check variety produced only 12.80 tha $^{-1}$. The data on fruit yield clearly pointed out that the yield of bhendi could be augmented by 37.21 per cent over the yield obtained under farmer's practices due to utilizing high yielding hybrid and implementation of suitable package of practices technology to cultivate the same. Similar results of yield improvement in various crops under frontline demonstrations has also been reported by Jeenangar et al.,[13], Hiremath et al., [14], Dhaka et al.,[10], Dudi and Meena [15], Patel et al.,[16], Singh and Sharma [17] Singh et al., [18], Singh and Sharma, [19].This positive impact resulted that, front line demonstration has given a confidence to the farming community as they were motivated to cultivate new bhendi hybrid Co 4 in lager extent.

The extension gap which recorded in this demonstration is $75.5 \mathrm{ha}^{-1}$ during the period of study call attention to educate the farmers through various means for implementing of superior horticultural techniques to overturn this tendency of broad extension gap. High yield performance of the non- descriptive varieties could be vanished due to uninterrupted cultivation of these varieties for years together. To improve the production and productivity any crop in particular regime, replacement of non-descriptive varieties seed by high yielding varieties is highly indispensable. Under these circumstances, Front Line Demonstration is acting an essential role in popularizing the improved variety of bhendi in the study area. 
There was a wide difference in technology gap observed in the demonstration yield over the potential yield. The average technology gap estimated in the experiment was $120.5 \mathrm{~kg} \mathrm{ha}^{-1}$ [Table2]. This could be because of the soil fertility and ecological status. Hence, location specific recommendations are obligatory to link the gap. These conclusion are comparable to the results of Mitra and Samajdar[20] and Katare et al. [21], Sharma and Sharma [22] and Patel et al.[16].The technology index recorded in the FLD was 37.19 per cent. The elevated range of technology index could be due to awareness and use of improved varieties and adoption of recommended scientific package of practices during the period of the study period. Importance of extension techniques for communicating to the farmers about the improved agro techniques for enhancing the productivity plays an essential role. The technology index showed the economic feasibility of the demonstrated technology at farmers field. Yadav et al., [23] also enlighten the impact of FLD in convincing the farmers for adoption of improved techniques for enhancing the crop productivity. Kacha and Patel, [24] also reported similar findings in bhendi under agro ecological conditions of Gujarat. Therefore, it concluded that understanding and using improved varieties / hybrids with recommended scientific package of practices enhanced the yield during implementation of FLD study period. Results of the current field trial are in agreement with the results of Singh et al., [25], Hiremath and Nagaraju[26], Dayanand et al.[27], Raj et al. [28], Meena and Singh [29], Bhargav et al., [30], Singh and Sharma [17] and Singh et al., [18].

\subsection{Economic Impact, [30], Singh and Sharma [17] and Singh et al}

The financial feasibility of superior technology over conventional farmer's practices was calculated based on the current prevailing market prices of inputs and output [tender vegetable] cost [Table 4]. The cost benefit analysis exposed that, cost of production of bhendi with improved technology reordered Rs. 43,000 ha-1 where as it recorded only Rs. 40600 $\mathrm{ha}^{-1}$ in farmers practice. The additional cost invested under improved technology was mainly due to additional cost for hybrid seed material. Front line demonstration with improved hybrid and systematic cultivation practices recorded higher net return of Rs. 78020 /h] with higher benefit cost ratio [2.80] and local variety recorded least values for net return [Rs. 36200/ha] and benefit cost ratio [1.90]. The results are in accordance with the findings of Hiremathetal.,[14], Hiremath and Nagaraju[26] and Patel et al.[16].

Table 2 Comparison of package of practices demonstrated and farmers practices under FLD on Bhendi hybrid Co 4

\begin{tabular}{|c|c|c|}
\hline Parameters & Package Demonstrated & Farmers practices \\
\hline Hybrid / variety & TNAU-Bhendi hybrid Co 4 & Traditional local variety \\
\hline Seed rate & $2.5 \mathrm{~kg} / \mathrm{ha}$ & $8-10 \mathrm{~kg} / \mathrm{ha}$ \\
\hline Seed treatment & $\begin{array}{l}\text { Seed treatment with Tricoderma viride @ } 4 \mathrm{~g} / \mathrm{kg} \text { or Pseudomonas } \\
\text { fluorescens @ } 10 \mathrm{~g} / \mathrm{kg} \text { of seeds and again with } 400 \mathrm{~g} \text { of } \\
\text { Azospirillum using starch as adhesive and dried in shade for } 20 \\
\text { minutes. }\end{array}$ & Not following \\
\hline Time of sowing & During June - August and February & Throughout the year \\
\hline Method of sowing & $\begin{array}{l}\text { Sow three seeds per hill at } 30 \mathrm{~cm} \text { apart and then thin to } 2 \text { plants } \\
\text { per hill after } 10 \text { days. }\end{array}$ & Broad casting \\
\hline Fertilizer dose & $\begin{array}{l}\text { Basal dose FYM @ } 40 \text { t / ha, N @ } 100 \text { kg, P @ } 100 \text { kg and K @ } 100 \\
\text { kg/ha as basal and } 100 \text { kg N / ha } 30 \text { at days after sowing. }\end{array}$ & No use of fertilizer \\
\hline Foliar nutrition & $\begin{array}{l}1 \% \text { urea }[10 \mathrm{~g} / \mathrm{l}]+\text { muriate of potash }[10 \mathrm{~g} / \mathrm{l}] \text { on } 30 \text { and } 45 \text { days } \\
\text { planting. } \\
\text { after } \\
\text { For hybrids, foliar application of water soluble fertilizer } 19-19- \\
19 \text { three times @ } 0.5 \%[5 \mathrm{~g} / \mathrm{l}] \text { at } 10 \text { days interval from } 30 \text { days } \\
\text { after planting }\end{array}$ & Nil \\
\hline Bio-fertilizers & $\begin{array}{l}\text { Apply Azospirillum and Phosphobacteria each at } 2 \mathrm{~kg} / \mathrm{ha} \text { mixed } \\
\text { with } 100 \mathrm{~kg} \text { of FYM before sowing. }\end{array}$ & Not following \\
\hline $\begin{array}{l}\text { Plant protection } \\
\text { measures }\end{array}$ & $\begin{array}{l}\text { Need based application of neem oil to protect } \\
\text { the crop against insect }\end{array}$ & Nil \\
\hline Irrigation & Irrigation is done at weekly intervals & $\begin{array}{l}\text { Irrigation at three days } \\
\text { interval }\end{array}$ \\
\hline Weed management & $\begin{array}{l}\text { Spray Oxyflourfen at } 0.15 \mathrm{~kg} \text { a.i./ha or as pre emergence } \\
\text { application on third day after sowing. Herbicide application } \\
\text { should be integrated with one hand weeding on } 30 \text { days after } \\
\text { sowing. }\end{array}$ & One hand weeding alone \\
\hline
\end{tabular}


Table 3 Effect on using bhendi hybrid Co-4 and adopting improved cultivation techniques over local practices on yield potential

\begin{tabular}{|c|c|c|c|c|c|c|c|c|c|c|c|c|}
\hline \multirow[t]{2}{*}{ Year } & \multirow[t]{2}{*}{ Variety } & \multirow[t]{2}{*}{$\begin{array}{l}\text { Area } \\
\text { [ha] }\end{array}$} & \multirow[t]{2}{*}{$\begin{array}{l}\text { Demo. } \\
\text { [No.] }\end{array}$} & \multirow[t]{2}{*}{$\begin{array}{l}\text { Potential } \\
\text { Yield } \\
\text { [qha-1] }^{-1}\end{array}$} & \multicolumn{4}{|c|}{$\begin{array}{l}\text { Demonstration yield of } \\
\text { improved technology } \\
{\left[\mathrm{qha}^{-1}\right]}\end{array}$} & \multirow[t]{2}{*}{$\%$ Increase } & \multirow[t]{2}{*}{$\begin{array}{l}\text { Extension } \\
\text { gap } \\
{\left[\text { qha }^{-1}\right]}\end{array}$} & \multirow[t]{2}{*}{$\begin{array}{l}\text { Technology } \\
\text { gap } \\
{\left[\text { qha }^{-1}\right]}\end{array}$} & \multirow[t]{2}{*}{$\begin{array}{l}\text { Technology } \\
\text { index [\%] }\end{array}$} \\
\hline & & & & & Max. & Min. & Avg. & Local & & & & \\
\hline $\begin{array}{l}2016-17 \\
\text { June- } \\
\text { September }\end{array}$ & $\begin{array}{l}\text { Bhendi } \\
\text { Hybrid } \\
\text { Co } 4\end{array}$ & 10 & 10 & 324.0 & 221.0 & 186.0 & 203.5 & 128.0 & 37.21 & 75.5 & 120.5 & 37.19 \\
\hline
\end{tabular}

Table 4 Effect on using bhendi hybrid Co-4 and adopting improved cultivation techniques over local practices on economics

\begin{tabular}{|c|c|c|c|c|c|c|c|c|c|c|c|c|c|c|}
\hline \multirow{2}{*}{$\begin{array}{l}\text { No. } \\
\text { of } \\
\text { Demo. }\end{array}$} & \multirow{2}{*}{$\begin{array}{l}\text { Area } \\
\text { [ha] }\end{array}$} & \multicolumn{4}{|c|}{ Yield [t/ha] } & \multirow{2}{*}{$\begin{array}{l}\% \\
\text { Increase } \\
\text { in yield }\end{array}$} & \multicolumn{4}{|c|}{${ }^{*}$ Economics of demonstration [Rs./ha] } & \multicolumn{4}{|c|}{$\begin{array}{l}\text { *Economics of check } \\
\text { [Rs./ha] }\end{array}$} \\
\hline & & \multicolumn{3}{|c|}{ Demonstration } & Check & & $\begin{array}{l}\text { Gross } \\
\text { Cost }\end{array}$ & $\begin{array}{l}\text { Gross } \\
\text { Return }\end{array}$ & $\begin{array}{l}\text { Net } \\
\text { Return }\end{array}$ & $\begin{array}{l}* * \\
\text { BCR }\end{array}$ & $\begin{array}{l}\text { Gross } \\
\text { Cost }\end{array}$ & $\begin{array}{l}\text { Gross } \\
\text { Return }\end{array}$ & $\begin{array}{l}\text { Net } \\
\text { Return }\end{array}$ & $\begin{array}{l}* * \\
\mathrm{BCR}\end{array}$ \\
\hline \multirow{2}{*}{10} & \multirow{2}{*}{10} & $\mathrm{H}$ & $\mathrm{L}$ & A & \multirow{2}{*}{12.80} & \multirow{2}{*}{37.21} & \multirow{2}{*}{43000} & \multirow{2}{*}{121020} & \multirow{2}{*}{78020} & \multirow{2}{*}{2.8} & \multirow{2}{*}{40600} & \multirow{2}{*}{76800} & \multirow{2}{*}{36200} & \multirow{2}{*}{1.9} \\
\hline & & 22.10 & 18.60 & 20.35 & & & & & & & & & & \\
\hline
\end{tabular}


Table 5 Effect on using bhendi hybrid Co-4 and adopting improved cultivation techniques over local practices on growth and yield characters

\begin{tabular}{|c|c|c|c|c|c|c|c|c|c|c|c|}
\hline Treatment & $\begin{array}{l}\text { Plant } \\
\text { height } \\
\text { [cm] }\end{array}$ & $\begin{array}{l}\text { No. } \\
\text { branches } \\
\text { / plant }\end{array}$ & $\begin{array}{l}50 \% \text { of } \\
\text { Flowering } \\
\text { [days] }\end{array}$ & $\begin{array}{l}\text { First } \\
\text { Fruit } \\
\text { Harvest } \\
\text { [days] }\end{array}$ & $\begin{array}{l}\text { No. of } \\
\text { fruits per } \\
\text { plant }\end{array}$ & $\begin{array}{l}\text { Individual } \\
\text { fruit } \\
\text { weight [g] }\end{array}$ & $\begin{array}{l}\text { Fruit } \\
\text { length } \\
\text { [cm] }\end{array}$ & $\begin{array}{l}\text { Fruit } \\
\text { girth } \\
\text { [cm] }\end{array}$ & $\begin{array}{l}\text { Yield } \\
\text { per } \\
\text { plant } \\
\text { [g] }\end{array}$ & $\begin{array}{l}\text { Yield } \\
\text { per ha } \\
\text { [q/ha] }\end{array}$ & $\begin{array}{l}\text { Incidence of } \\
\text { YVM } \\
\text { disease [\%] }\end{array}$ \\
\hline Hybrid Co 4 & 125.3 & 3.4 & 51.0 & 40.9 & 20.4 & 15.6 & 13.7 & 7.1 & 437.8 & 203.5 & 3.8 \\
\hline Check & 116.2 & 3.2 & 62.0 & 56.8 & 16.2 & 13.5 & 10.8 & 5.8 & 378.5 & 128.0 & 21.5 \\
\hline SD & 6.43 & 0.14 & 7.78 & 11.24 & 2.97 & 1.48 & 2.05 & 0.92 & 41.93 & 52.11 & 18.38 \\
\hline $\mathrm{CV}$ & 5.33 & 4.29 & 13.77 & 23.02 & 16.23 & 10.21 & 16.74 & 14.25 & 10.27 & 31.61 & 114.90 \\
\hline
\end{tabular}

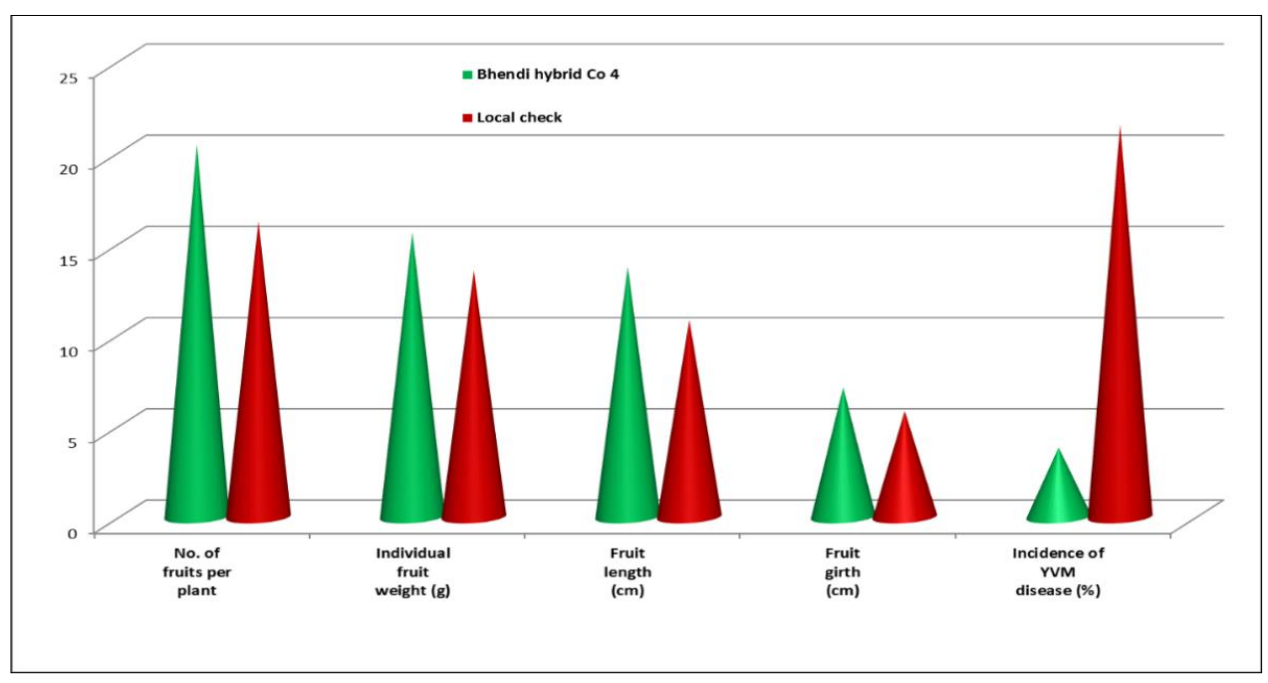

Figure 1 Effect on using bhendi hybrid Co-4 and adopting improved cultivation techniques over local practices on yield characters 


\section{Conclusion}

The findings of this front line demonstration showed that the yield under cultivation of bhendi was amplified by 37.21 per cent due to technological interventions adopted during the study period. The findings noticeably recognized that the implementation of superior technology augmented the bhendi crop productivity and farmers economic profitability. Large number of farmers in the villages of Thiruvarur district adopted the recommended practices of demonstrations and got benefitted with higher bhendi production because of influence of Front Line Demonstration study which played a vital role and brought boon to the farming community.

\section{Compliance with ethical standards}

\section{Acknowledgments}

The authors acknowledge the ICAR - KVK, Thiruvarur for supporting financially and the farmers group for their complete support towards the execution of this Front Line Demonstrations.

\section{Disclosure of conflict of interest}

The author declares no conflict of interest.

\section{References}

[1] Siva Ranjani P, Ebenezer Babu Rajan R, Praveen Sampath Kumar C, Joshi J L and Sam Ruban J. Evaluation of hybrids for growth, yield and its component traits in bhendi [Abelmoschus esculentus L. Moench]. Plant Archives, 2019[2], 3011-3014.

[2] Ndunguru J, Rajabu AC. Effect of okra mosaic virus disease on the above-ground morphological yield components of okra in Tanzania. Scientia Horticulturae. 2004 Feb 27;99(3-4): 225-35.

[3] Gemede HF, Ratta N, Haki GD, Woldegiorgis AZ, Beyene F. Nutritional quality and health benefits of okra (Abelmoschus esculentus): A review. J Food Process Technol. 2015 Mar 21;6(458): 2.

[4] Nagrajan S, Singh RP, Singh R, Singh S, Singh A, Kumar A, Chand R. Transfer of technology in wheat through front line demonstration in India, A comprehensive report, 1995-2000, Directorate of Wheat Research, Karnal 132001. Research Bulletin. 2001(6).

[5] Samui SK, Maitra S, Roy DK, Mandal AK, Saha D. Evaluation of front line demonstration on groundnut. Journal of the Indian Society Costal Agricultural Research. 2000;18(2): 180-3.

[6] Kadian KS, Sharma R, Sharma AK. Evaluation of frontline demonstration trials on oilseeds in Kangra Valley of Himachal Pradesh. Annals of Agriculture Research. 1997;18(1): 40-3.

[7] Sagar R, Chandra G. Frontline demonstration on sesame in West Bengal. Agriculture Extension Review. 2004;16(2): 7-10.

[8] Sivakumar V, Kamaraj A and Baskaran R. Performance of Cluster Bean Variety MDU 1 in Thiruvarur District, India. International Journal of Current Microbiology and Applied Sciences. 2020; 9[7]: 3697-3703.

[9] Kumaran M, Vijayaragavan K. Farmers' satisfaction of agricultural extension services in an irrigation command area. Indian Journal of Extension Education. 2005;41(3\&4): 8-12.

[10] Dhaka BL, Meena BS, Suwalka RL. Popularization of improved maize production technology through frontline demonstrations in south-eastern Rajasthan. Journal of Agricultural Sciences. 2010 Jul 1;1(1): 39-42.

[11] Ranawat Y, Ram H, Sisodiya SS, Punjabi NK. Adoption of improved maize cultivation practices by trained and untrained farmers of KVK, Udaipur. Rajasthan Journal of Extension Education. 2011;19: 144-7.

[12] Sreelakshmi CH, Sameer Kumar CV, Shivani D. Productivity Enhancement of Pigeonpea (Cajanus cajan L.) Through Improved Production Technologies. Madras Agricultural Journal. 2012;99(4-6): 248-50.

[13] Jeengar KL, Panwar P, Pareek OP. Front line demonstration on maize in Bhilwara district of Rajasthan. Current Agriculture. 2006;30(1/2): 115-6. 
[14] Hiremath SM, Nagaraju MV, Shashidhar KK. Impact of front line demonstrations on onion productivity in farmer's field. In: National Seminar on Appropriate Extension Strategies for Management of Rural Resources, University of Agricultural Sciences, Dharwad, December 2007 Dec 18 (pp. 18-20).

[15] Dudi A, Meena ML. Adoption of improved mustard production technology in Pali district of Rajasthan. Int J Ext Edu. 2012;8: 5-8.

[16] Patel MM, Jhajharia AK, Khadda BS, Patil LM. Front line demonstration: An effective communication approach for dissemination of sustainable cotton production technology. Ind. J. Extn. Edu. \& RD. 2013;21: 60-2.

[17] Bhagwan S, Sharma AK. Dissemination of improved technology of moth bean through front line demonstrations in arid zone. International Journal of Tropical Agriculture. 2016;34(6): 1599-602.

[18] Singh B, Anurag S, Ashutosh S and Atul D. Impact of Front Line Demonstrations on Barley Production in Arid Zone. International Journal of Tropical Agriculture, 2016;34(6); 1603-1606.

[19] Singh B, Sharma AK. Impact of front line demonstrations on productivity enhancement of cumin in arid zone. International J. Seed Spices. 2017 Jul;7(2): 72-76.

[20] Mitra B, Samajdar T. Yield gap analysis of rapeseed-mustard through front line demonstration. Agric. Exten. Review. 2010;22: 16-17.

[21] Katare S, Pandey SK, Mustafa M. Yield gap analysis of Rapeseed-mustard through front line demonstrations. Agric. update. 2011 Mar;6(2): 5-7.

[22] Sharma R N and Sharma K C. Evaluation of front line demonstration on groundnut [Arachis hypogea L.]. J. Indian Society Coastal Agri. Res,2004;18;180-183.

[23] Yadav V P S, Kumar R, Deshwal A K, Rama R S, Sharma B K and Bhela S L. Boosting Pulse Production through Frontline Demonstraton. Indian Research Journal of Extension Education, 2007;7;[2\&3].

[24] KACHA HL, PATEL SK. Impact of frontline demonstration on okra (Abelmoschus esculentus (L.) Moench) yield improvement. Journal of Agri Search. 2015 Mar 10;2(1).

[25] Singh DK, Gautam US, Singh RK. Study on yield gap and level of demonstrated crop production technology in Sagar district. Indian Research Journal of Extension Education. 2007;7(2\&3): 94-5.

[26] Hiremath SM, Nagaraju MV. Evaluation of front line demonstration trials on onion in Haveri district of Karnataka. Karnataka Journal of Agricultural Sciences. 2009;22(5): 1093-4.

[27] Dayanand RK, Mehta SM. Boosting mustard production through front line demonstrations. Indian Research Journal of Extension Education. 2016 Jan 16;12(3): 121-3.

[28] Raj AD, Yadav V, Rathod JH. Impact of front line demonstrations (FLD) on the yield of pulses. International Journal of Scientific and Research Publications. 2013 Sep;3(9): 1-4.

[29] Meena M L and Singh D. Impact of front line demonstration [FLD] in adoption of gram production Technology. International Journal of Scientific and Research 2014; 55;(2);277-283.

[30] Bhargav KS, Pandey A, Sharma RP, Singh A, Kumar M. Evaluation of Front Line Demonstration on chickpea in Dewas District. Indian Journal of Extension Education. 2015;51(3and4): 159-61. 